\title{
Pelatihan Desain 3D Menggunakan Sketch Up Guna Mendukung Kinerja Bidang Kewilayahan Pemerintahan Desa Karangturi Banyumas
}

\author{
Kuat Indartono*1, Bagus Adhi Kusuma², Hellik Hermawan33, Nur Adhy Yusuf Kurniawan4 \\ ,1,2,3Universitas Amikom Purwokerto \\ ${ }^{3}$ Program Studi Informatika, Fakultas Ilmu Komputer, Universitas Amikom Purwokerto, Indonesia \\ *e-mail: indartono@amikompurwokerto.ac.id ${ }_{2}{ }_{2}$ bagus@amikompurwokerto.ac.id $^{2}{ }_{2}$ \\ hellikhermawan @amikompurwokerto.ac.id ${ }^{3}$, adhyyusuf123@gmail.com ${ }^{4}$
}

\begin{abstract}
Abstrak
Desa Karangturi merupakan salah satu dari 19 desa yang ada di Kecamatan Sumbang. Perkembangan dan kemandirian suatu desa tergantung dari produktivitas individu dan organisasi Pemerintahan Desa. Berdasarkan hasil wawancara dengan salah satu perangkat desa Bapak Nasrul menyampaikan beberapa permasalahan, salah satunya adalah sekitar 50\% dari penduduk desa pada usia produktif belum memiliki soft skill yang memadai. Permasalahan lainnya adalah bahwa dari pekerjaan aparatur desa dibutuhkan soft skill yang dapat meringankan pekerjaan tersebut yaitu berupa perencanaan dan desain tata ruang desa serta peta sosial desa. Solusi yang ditawarkan untuk mengatasi masalah mitra yaitu, memberikan pelatihan desain 3D menggunakan Sketch Up guna mendukung kinerja Bidang Kewilayahan Pemerintahan Desa Karangturi, Kabupaten Banyumas. Metode yang digunakan yaitu dengan memberikan pelatihan 3D menggunakan Sketch Up dan dievaluasi dengan menggunakan kuesioner untuk mengetahui tingkat pemahaman peserta. Kegiatan ini berlangsung selama dua hari dengan memberikan materi dasar menggambar di hari pertama dan membuat desain 3D di hari kedua dengan menggunakan software Sketch Up. Hasil dari pelatihan ini berupa desain 3D rumah sederhana yang dibuat oleh peserta. Tingkat kepuasan peserta pelatihan tercapai 70\% pada level puas, 20\% pada level sangat puas dan 10\% netral. Peserta yang sudah mendapatkan modal berupa pelatihan desain 3D menggunakan Sketch Up diharapkan mampu mengembangkan skill yang dimiliki untuk mendesain infrastruktur fisik desa.
\end{abstract}

Kata kunci: bidang kewilayahan, desain 3D, Desa Karangturi, sketch up.

\begin{abstract}
Karangturi Village is one of 19 villages in the Subdistrict of Sumbang. The development and independence of a village depend on the productivity of the individual and village government organizations. Based on the results of an interview with one of the governments of the village, Mr Nasrul, he conveyed several problems, one of which was that around 50\% of the village population of productive age did not have adequate soft skills. Another problem is that from the work of village government, soft skills are needed that can ease the work in the form of village spatial planning and design as well as village social maps. The solution offered to overcome partner problems is to provide 3D design training using Sketch Up to support the performance of the Regional Government of Karangturi Village, Banyumas District. The method used is to provide 3D training using Sketch Up and evaluated using a questionnaire to determine the level of understanding of the participants. This activity lasted for two days by providing basic drawing materials on the first day and making 3D designs on the second day using Sketch Up software. The result of this training is a simple $3 D$ house design made by the participants. The level of satisfaction of the training participants reached $70 \%$ at the level of satisfied, $20 \%$ at the level of very satisfied and $10 \%$ neutral. Participants who have received the knowledge of $3 D$ design training using Sketch Up are expected to be able to develop their skills to design village physical infrastructure.
\end{abstract}

Keywords: Karangturi Village, sketch up, territorial area, 3D design.

\section{PENDAHULUAN}

Pemerintahan Desa adalah penyelenggaraan urusan pemerintahan dan kepentingan masyarakat setempat dalam sistem pemerintahan Negara Kesatuan Republik Indonesia[1][2][3]. Desa Karangturi merupakan salah satu dari 19 desa yang ada di Kecamatan Sumbang[4]. Maju dan mandiri suatu desa tergantung dari produktivitas individu dan organisasi Pemerintahan Desa [5]. 
Pemerintahan Desa terdiri dari Kepala Desa, Badan Permusyawaratan Desa (BPD), Sekretaris, Pelaksana Teknis dan Pelaksana Kewilayahan. Kepala Desa bertugas menyelenggarakan pemerintahan desa, melaksanakan pembangunan desa, pembinaan kemasyarakatan desa, dan pemberdayaan masyarakat desa. Sekretaris Desa bertugas membantu Kepala Desa dalam bidang administrasi pemerintahan. Sekretaris dibantu Kasi Pemerintahan, Kasi Pelayanan dan Kasi Kesejahteraan [6]. Masing-masing Kasi memiliki tugas dan fungsi yang berbeda-beda. Kasi Pemerintahan bertugas membantu pelaksanaan tugas operasional. Kasi Pelayanan bertugas membantu tugas operasional dibidang pelayanan. Kasi Kesejahteraan tugasnya meliputi pelaksanaan pembangunan sarana prasarana perdesaan, pembangunan bidang pendidikan dan kesehatan.

Organisasi lain dalam pemerintahan desa yaitu Pemberdayaan Kesejahteraan Keluarga (PKK) dan Karang Taruna. Karang Taruna dijadikan sebagai kaderisasi masyarakat usia muda untuk membantu pemerintahan desa. Karang Taruna dibekali dengan kemampuan soft skill untuk menyiapkan generasi yang siap kerja dan berwiraswasta sesuai dengan program pemerintah desa setiap tahun.

Desa Karangturi memiliki penduduk sebanyak 2.852 Orang, terdiri dari Laki-laki: 1.441 orang dan Perempuan: 1.411 orang. Dilihat dari tingkat pendidikan hampir 50\% penduduk desa karang taruna pada usia produktif dan berpendidikan SLTP dan SLTA [7].

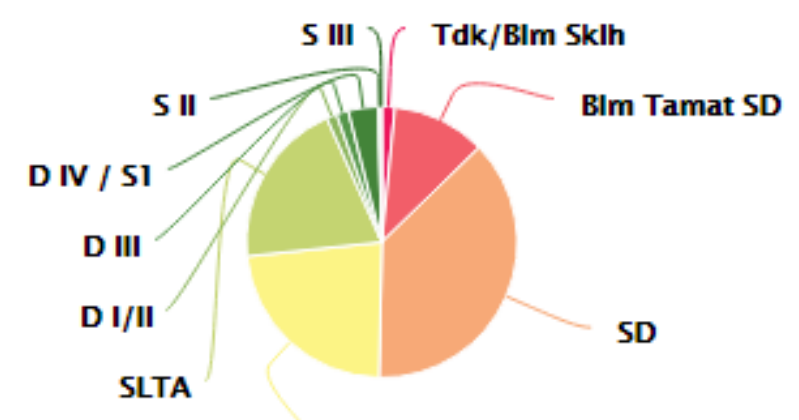

SLTP

Gambar 1. Penduduk Desa Karangturi berdasarkan tingkat pendidikan

Banyaknya usia produktif warga Desa Karangturi ini merupakan bonus demografi tersendiri. Berdasarkan hasil wawancara dengan Bapak Nasrul selaku perangkat Desa mengatakan bahwa penduduk dengan usia produktif ini jika dibekali dengan soft skill akan sangat membatu mereka dalam upaya mencari pekerjaan. Disamping itu perangkat desa perlu juga dibekali dengan soft skill untuk menunjang kinerja mereka.

Dari hasil wawancara tersebut maka dapat dirumuskan permasalahan yang ada pada mitra yaitu penduduk dengan usia produktif hampir $50 \%$ yang merupakan penduduk siap kerja perlu dibekali dengan soft skill supaya mampu bersaing dan kebutuhan akan soft skill untuk menunjang keberhasilan pekerjaan Pemerintahan Desa sangat diperlukan yang berkaitan dengan perencanaan dan desain pembangunan desa seperti pembangunan tata ruang desa, peta sosial desa, talud, dan fasilitas umum lainnya.

Berdasarkan permasalahan yang dihadapi mitra, solusi yang ditawarkan adalah memberikan pelatihan soft skill berupa desain 3D dengan Software Sketch Up kepada Perangkat, anggota Karang taruna dan penduduk usia produktif, pendampingan kaderisasi untuk kebutuhan penunjang perencanaan pembangunan desa dengan mencari peserta yang berkompeten dari hasil pelatihan 3D Sketch Up untuk diperbantukan di Desa. Desain 3D adalah sebuah desain objek atau ruang yang memiliki panjang, lebar dan tinggi yang memiliki bentuk[8]. Software Sketch Up adalah program grafis 3D yang dikembangkan oleh Google yang mengkombinasikan seperangkat alat (tools) yang sederhana, namun sangat handal dalam desain grafis 3D di dalam layar komputer[9]. Gambar 2 merupakan foto Kantor Desa Karangturi, yang menjadi tempat pengabdian dan Gambar 3 merupakan peta lokasi kegiatan pengabdian. Luaran 
yang dihasilkan berupa kemampuan untuk mendesain 3D menggunakan Sketch Up bagi peserta, jurnal pengabdian, video pelaksanaan pengabdian dan publikasi di media cetak/elektronik.
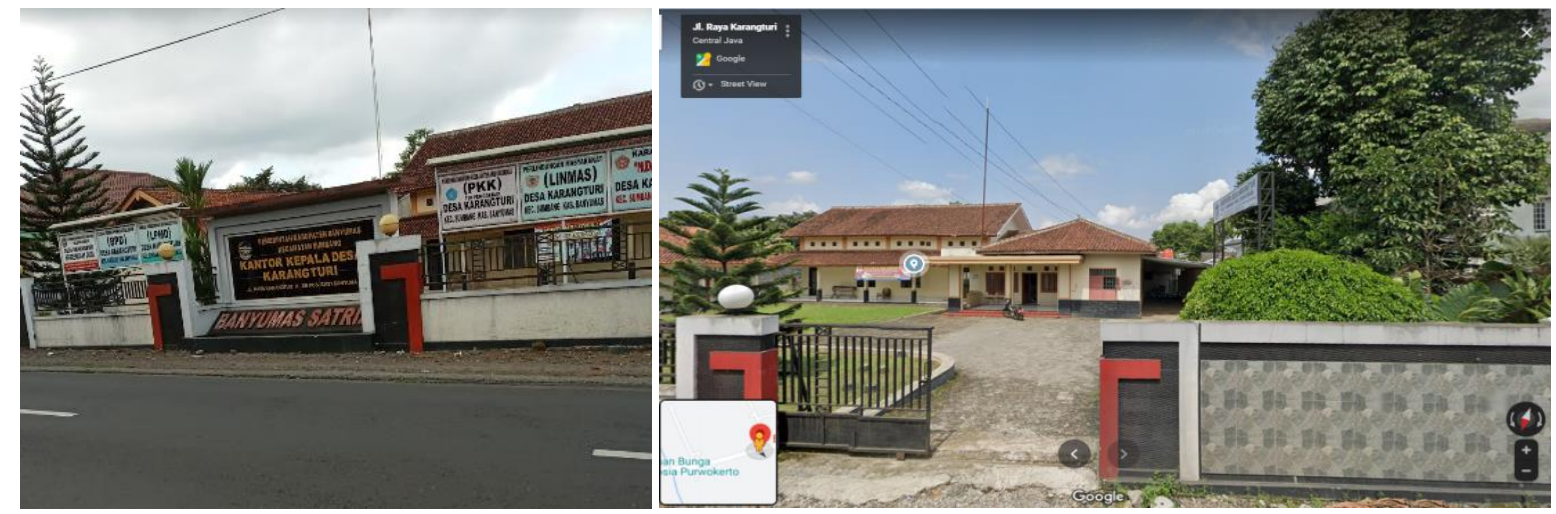

Gambar 2. Kantor Desa Karangturi

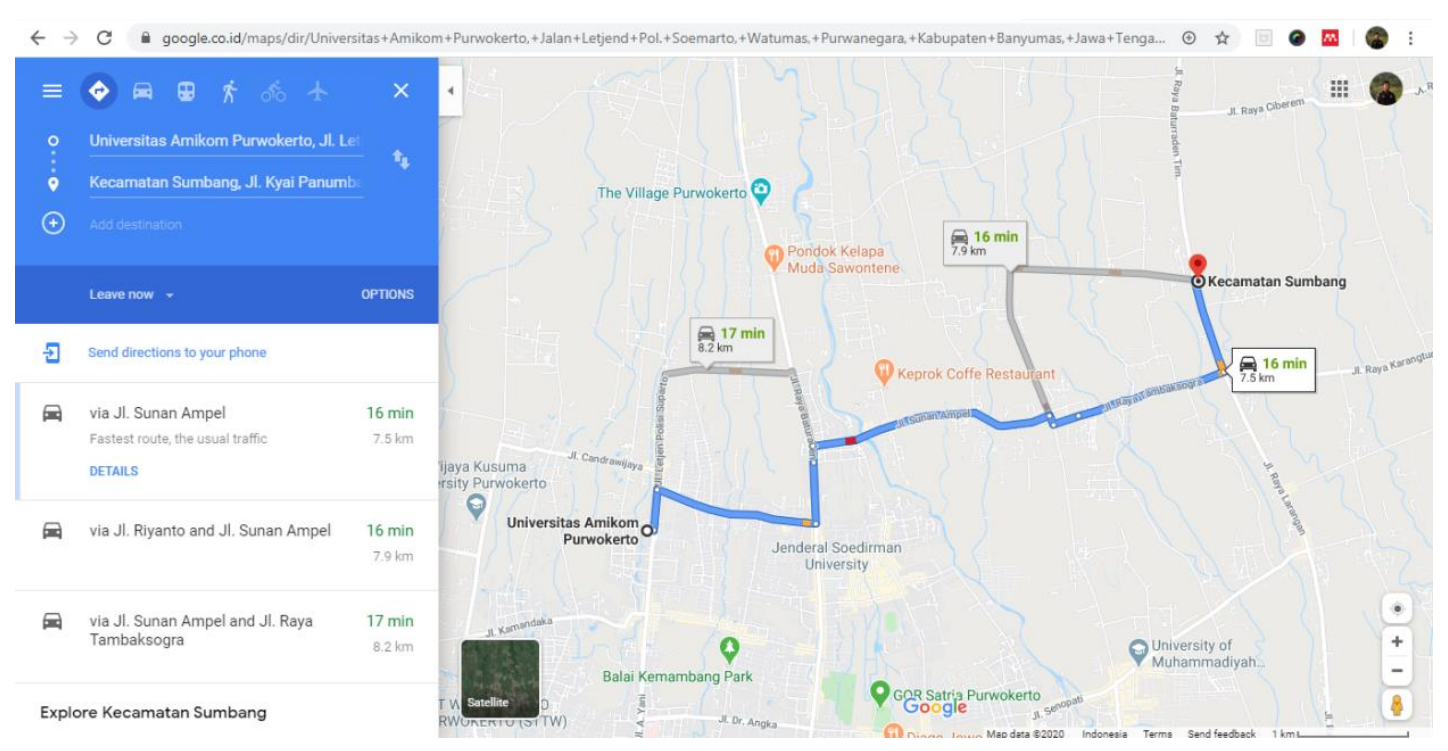

Gambar 3. Peta lokasi kegiatan pengabdian

\section{METODE}

Metode pelaksanaan pengabdian kepada masyarakat dilalui dengan beberapa tahapan, yang pertama pembentukan tim pelaksana yang terdiri dari satu Dosen dan dua mahasiswa sebagai anggota. Tahap berikutnya observasi dilakukan dengan mengunjungi Desa Karangturi Kecamatan sumbang dan melakukan wawancara dengan perangkat desa untuk mengetahui permasalahan yang dihadapi oleh desa tersebut. Perangkat yang dijadikan narasumber yaitu Bapak Nasrul, diperoleh permasalahan berupa pemberian soft skill untuk usia produktif.

Selanjutnya memberikan pelatihan sebagai prioritas solusi masalah dengan memberikan soft skill berupa desain 3D dengan Software Sketch Up. Hasil dari pelatihan ini diharapkan mampu menguasai desain 3D untuk bidang perencanaan dan desain dan juga bidang yang lainnya sesuai kemampuan eksplorasi dari peserta.

Tahap terakhir berupa review pelaksanaan kegiatan dan evaluasi. Evaluasi adalah penyediaan informasi yang dapat dijadikan sebagai bahan pertimbangan dalam mengambil keputusan[10]. Evaluasi pada pelatihan ini dilakukan dengan memberikan 
kuesioner untuk mengetahui tingkat kepuasan peserta pelatihan dengan jumlah pertanyaan 11 butir.

\section{HASIL DAN PEMBAHASAN}

Program Amikom Mitra Masyarakat di Desa Karangturi Kecamatan Sumbang Banyumas berlangsung selama 2 hari, hari Senen 7 Juni dan hari Selasa 8 Juni 2021. Pelatihan Desain 3d Menggunakan Sketch Up Guna Mendukung Kinerja Bidang Kewilayahan Pemerintahan Desa Karangturi diikuti oleh 12 peserta, perangkat desa dan dari perwakilan karang taruna. Hari Pertama diberikan materi berupa teknik dasar menggambar 3D dan dilanjutkan dengan praktek membuat lantai, membuat kolom dan dinding. Hari kedua melanjutkan pelatihan yaitu membuat kusen dan membuat atap. Gambar 4 merupakan foto dokumentasi pada saat pelatihan hari pertama dan hari Kedua.

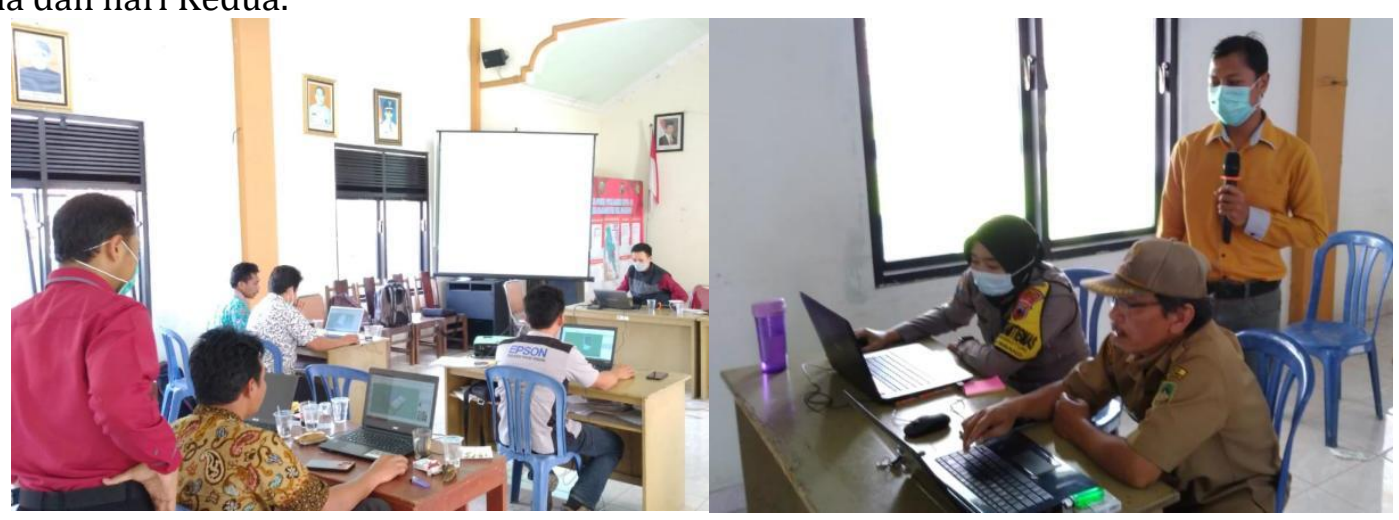

Gambar 4. Pelaksanaan Pelatihan di Aula Balai Desa Karangturi

Hasil akhir dari Pelatihan Desain 3d Menggunakan Sketch Up yaitu berupa desain rumah sederhana 3D seperti yang terlihat pada Gambar 5.

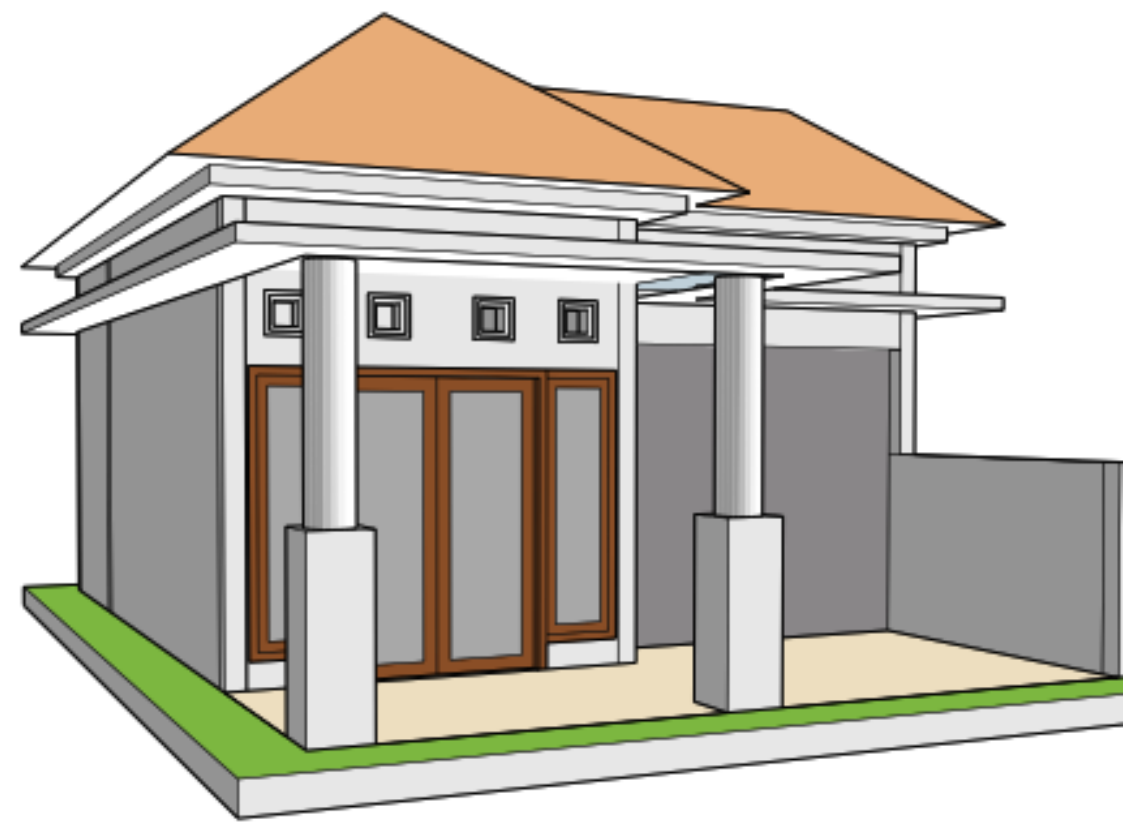

Gambar 5. Hasil Pelatihan Desain 3d Menggunakan Sketch Up

Pada akhir acara dilakukan review pelaksanaan kegiatan dan evaluasi. Hasil review kegiatan tersebut berjalan dengan lancar selama dua hari, kesiapan peserta sangat baik mengingat mereka sangat antusias dengan membawa laptop sendiri dan 
tempat sangat memadahi dengan meja dan kursi sesuai kebutuhan peserta. Evaluasi pelaksanaan kegiatan pelatihan ini dilakukan dengan mengisikan kuesioner peserta pelatihan dengan menggunakan google form. Hasil kuesioner peserta pelatihan dapat dilihat pada Tabel 1.

Tabel 1. Kuesioner Kepuasan Kegiatan Pengabdian kepada Masyarakat (PkM)

\begin{tabular}{|c|c|c|c|c|c|c|}
\hline No & Pertanyaan & STS & TS & $\mathbf{N}$ & $S$ & SS \\
\hline 1 & Materi PkM sesuai dengan kebutuhan Mitra & - & - & 1 & 4 & 5 \\
\hline 2 & Kegiatan PkM yang dilaksanakan sesuai harapan & - & - & 1 & 5 & 4 \\
\hline 3 & Cara narasumber menyajikan materi PkM menarik & - & - & 1 & 8 & 1 \\
\hline 4 & Materi yang disajikan jelas dan mudah dipahami & - & - & 1 & 7 & 2 \\
\hline 5 & $\begin{array}{l}\text { Waktu yang disediakan sesuai untuk penyampaian } \\
\text { materi dan kegiatan PkM }\end{array}$ & - & - & 1 & 8 & 1 \\
\hline 6 & $\begin{array}{l}\text { Mitra berminat untuk mengikuti kegiatan PkM } \\
\text { selama sesuai dengan kebutuhan Mitra/peserta }\end{array}$ & - & - & 1 & 8 & 1 \\
\hline 7 & $\begin{array}{l}\text { Anggota PkM yang terlibat dalam kegiatan } \\
\text { pengabdian masyarakat memberikan pelayanan } \\
\text { sesuai dengan kebutuhan }\end{array}$ & - & - & 1 & 6 & 3 \\
\hline 8 & $\begin{array}{l}\text { Setiap keluhan/pertanyaan/permasalahan yang } \\
\text { diajukan ditindaklanjuti dengan baik oleh } \\
\text { narasumber/anggota pengabdian yang terlibat }\end{array}$ & - & - & 1 & 8 & 1 \\
\hline 9 & $\begin{array}{l}\text { Mitra mendapatkan manfaat langsung dari } \\
\text { kegiatan PkM yang dilaksanakan }\end{array}$ & - & - & 1 & 7 & 2 \\
\hline 10 & $\begin{array}{l}\text { Kegiatan PkM berhasil meningkatkan kemampuan } \\
\text { peserta }\end{array}$ & - & - & 1 & 8 & 1 \\
\hline 11 & Secara umum, mitra puas terhadap kegiatan PkM & - & - & 1 & 8 & 1 \\
\hline
\end{tabular}

Hasil kuesioner peserta pelatihan Sketch Up, terkait kebutuhan peserta terhadap pelatihan tersebut 10\% Netral, 40\% Setuju dan 50\% Sangat Setuju seperti pada Gambar 6.

Materi PkM sesuai dengan kebutuhan Mitra

10 responses

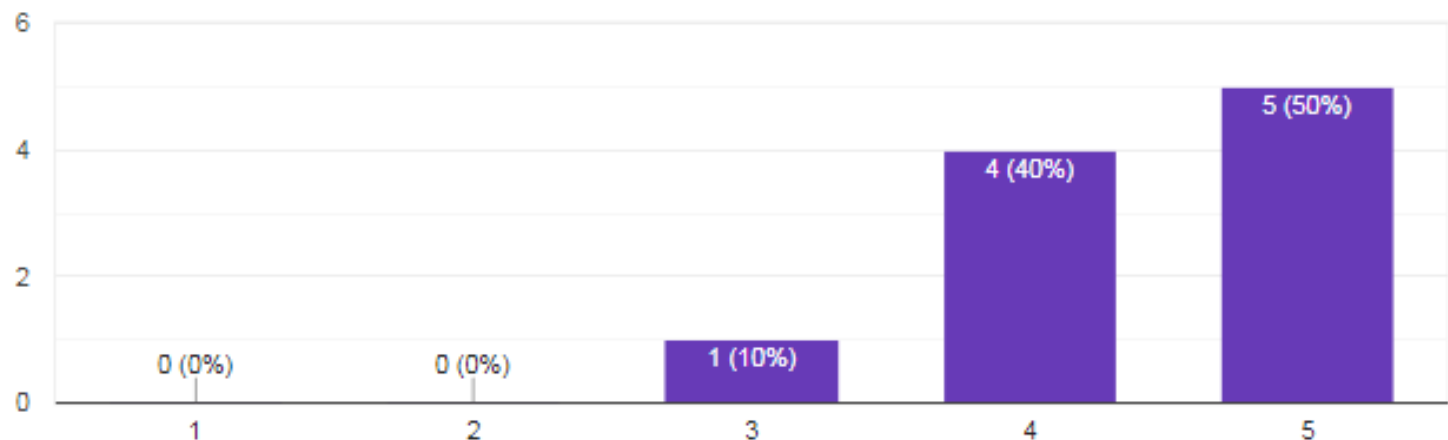

Gambar 6. Hasil kuesioner kebutuhan peserta terhadap pelatihan

Hasil kuesioner peserta pelatihan Sketch Up, terkait manfaat pelatihan sesuai harapan: 10\% Netral, 50\% Sesuai dan 40\% Sangat Sesuai seperti pada Gambar 7. 


\section{Kegiatan PkM yang dilaksanakan sesuai harapan}

10 responses

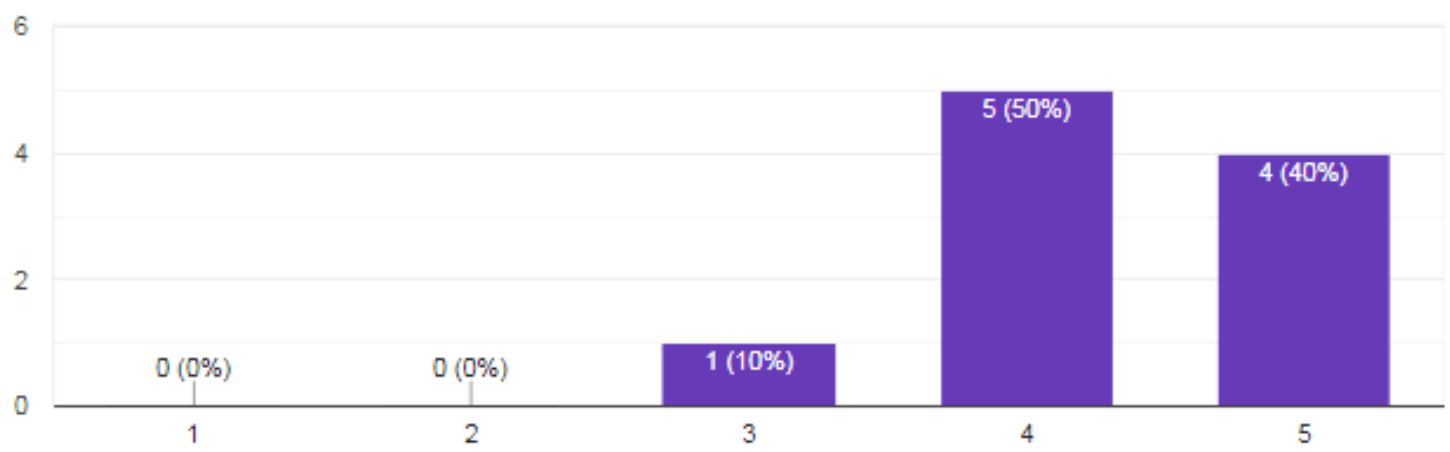

Gambar 7. Hasil kuesioner manfaat pelatihan sesuai harapan

Hasil kuesioner peserta pelatihan Sketch Up, terkait pemahaman peserta terhadap materi pelatihan: $10 \%$ Netral, 70\% Paham dan 20\% Sangat Paham seperti pada Gambar 8.
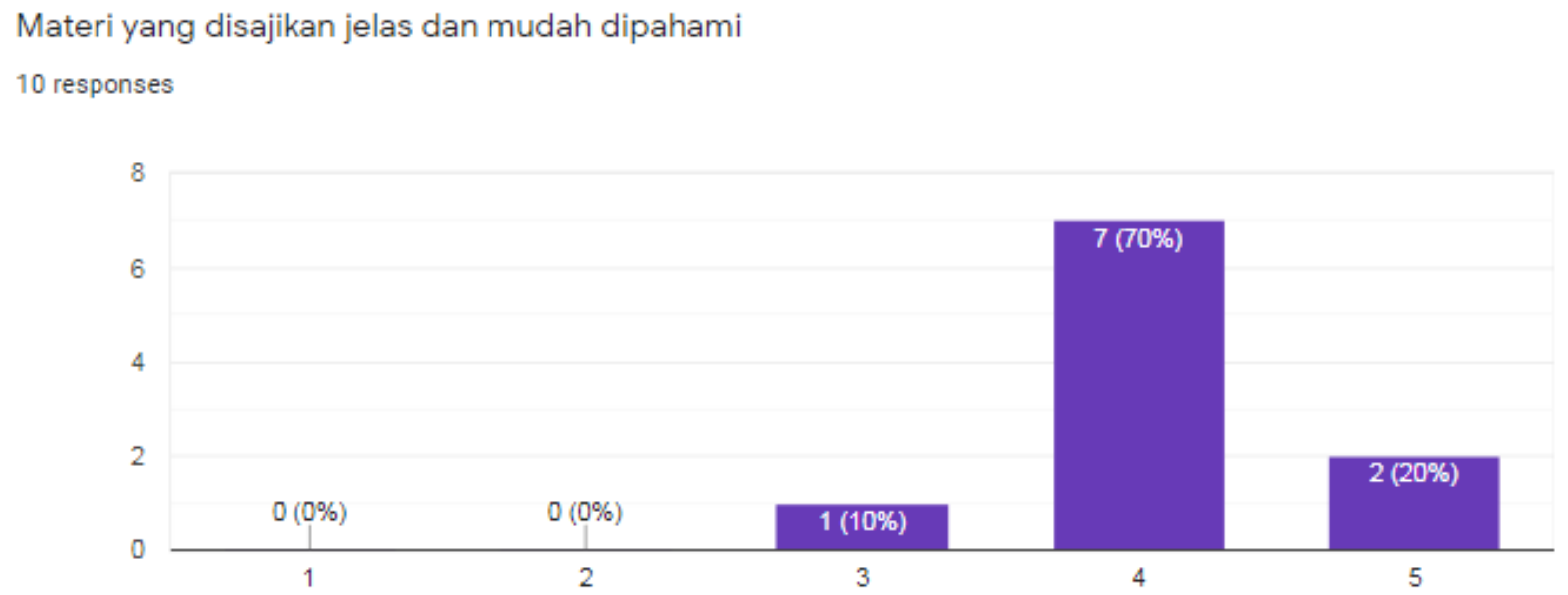

Gambar 8. Hasil kuesioner tingkat pemahaman peserta terhadap materi pelatihan

\section{KESIMPULAN}

Pelaksanaan pelatihan desain 3D menggunakan Sketch Up yang diberikan kepada perangkat desa bidang kewilayahan pemerintahan desa Karangturi Kecamatan Sumbang berjalan dengan lancar dan tertib. Para peserta sangat antusias dalam mengikuti pelatihan tersebut. Pelatihan ini memberi pembekalan berupa skill penggunaan aplikasi Sketch Up untuk menggambar 3D. Tingkat pemahaman peserta pelatihan tercapai $70 \%$ pada level Paham dan $20 \%$ pada level Sangat Paham. Para peserta yang sudah mendapatkan modal berupa pelatihan desain 3D menggunakan Sketch Up diharapkan mampu mengembangkan skill yang dimiliki untuk mendesain infrastruktur fisik desa.

\section{UCAPAN TERIMA KASIH}

Terimakasih kami ucapkan kepada Lembaga Penelitian dan Pengabdian Kepada Masyarakat (LPPM) atas pendanaan yang diberikan kepada kami melalui program Amikom Mitra Masyarakat (AMM) Tahun 2021, serta kepada Pemerintahan Desa Karangturi atas fasilitas dan dukungan tempat sehingga acara Pengabdian dapat berjalan dengan lancar dan sukses. 


\section{DAFTAR PUSTAKA}

[1] UU Republik Indonesia No 6 Tahun 2014 Tentang Desa. Indonesia.

[2] Ulfah Andriani and Tatik Zulaika, "Peran Perangkat Desa Dalam Akuntabilitas Pengelolaan Dana Desa," J. Akad. Akunt., vol. 2, no. 2, pp. 119-144, 2019.

[3] A. Ardiansah and S. Oktapani, "Pemahaman Hak Dan Kewajiban Masyarakat Desa Tanjung Karang," Community Dev. J. J. Pengabdi. Masy., vol. 1, no. 2, pp. 95-103, 2020.

[4] “Kecamatan Sumbang Dalam Angka 2020," 2020. https://banyumaskab.bps.go.id/publication/2020/09/28/04dd2fe483e8d74cdd999c4b/ kecamatan-sumbang-dalam-angka-2020.html.

[5] G. J. E. Undap, E. R. Sondakh, and A. Rorong, "Hubungan Motivasi, Produktivitas Dan Budaya Kerja Aparat Pemerintah Desa Dengan Efektifitas Keberhasilan Pembangunan Desa," Eksekutif, vol. 4, no. 4, pp. 1-12, 2019.

[6] S. Sugiman, "Pemerintahan Desa," Binamulia Huk., vol. 7, no. 1, pp. 82-95, 2018, doi: 10.37893/jbh.v7i1.16.

[7] "DINAS PEMBERDAYAAN MASYARAKAT, DESA, KEPENDUDUKAN DAN PENCATATAN SIPIL PROVINSI JAWA TENGAH." https://sidesa.jatengprov.go.id/desa/33.02.21.2002.

[8] I. F. Faiztyan, R. R. Isnanto, and E. D. Widianto, "Perancangan dan Pembuatan Aplikasi Visualisasi 3D Interaktif Masjid Agung Jawa Tengah Menggunakan Unity3D," J. Teknol. dan Sist. Komput., vol. 3, no. 2, p. 207, 2015, doi: 10.14710/jtsiskom.3.2.2015.207-212.

[9] S. I. A. Setiawan, "Google SketchUp Perangkat Alternatif dalam Pemodelan 3D," J. Ultim., vol. 3, no. 2, pp. 6-10, 2011, doi: 10.31937/ti.v3i2.298.

[10] S. Eko Putro Widoyoko, "Evaluasi Program Pelatihan," pp. 1-17. 
